\title{
Lipoid Pneumonia for Two Cases
}

\author{
İki Olgu Nedeniyle Lipoid Pnömoni
}

Songül Özyurt' ${ }^{1}$ Mevlüt Karataş', Aziz Gümüş', Halit Çınarka', Ayşe Ertürk², Servet Kayhan', Ünal Şahin'

\begin{abstract}
Lipoid pneumonia is a rare form of pneumonia. There are two types; exogenous and endogenous. The exogenous form often occurs due to accidental aspiration of fatty substances (such as; animal, vegetable or mineral fats). For elderly patients inparticular, the most common causes are oily nose drops and the use of oily substances for laxatives, such as castor oil. They are compounds containing hydrocarbons and hydrogen. The most common example is the oil found in paraffin, olefins, aromatics and the the acetylene series. Aspiration of high viscosity petroleum hydrocarbons may cause lipoid pneumonia. The accidental aspiration of hydrocarbon compounds can also cause acute illnesses such as fire eaters' pneumonia. In particular, the storing of hydrocarbon compounds in inappropriate packaging in the home, such as water, fruit juice or carbonated beverage bottles, are important factors facilitating the accidental drinking of these compounds by children. Since it does not have any specific clinic and radiological finding, it may be difficult to diagnose it, unless there is strong suspicion, or data is derived from anamnesis. Though a more common form of serious poisoning in childhood, in this study we, present two cases of lipoid pneumonia, diagnosed in adults.
\end{abstract}

Key words: Lipoid pneumonia, hydrocarbon, aspiration.

\section{Özet}

Lipoid pnömoniler pnömoninin nadir bir formudur. Eksojen ve endojen olmak üzere iki tipi vardır. Eksojen formu genellikle yağlı maddelerin (hayvansal, bitkisel ya da mineral yağlar) kaza ile aspirasyonu sonucu meydana gelir. Özellikle yaşlı hastalarda yağlı burun damlaları, laksatif amaçlı hint yağı gibi maddelerin kullanılması en sık sebeplerdir. Hidrokarbonlar ve hidrojen içeren bileşiklerdir. En yaygın örneği olan petrol; parafin, olefin, aromatikler ve asetilen serisinden oluşan bileşimidir. Petrol ürünlerinde bulunan yüksek viskoziteli hidrokarbonların aspirasyonuna bağlı lipoid pnömoni gelişebilir. Ayrıca hidrokarbon bileşiklerinin kaza sonucu aspirasyonu ateş yiyenlerin pnömonisi gibi akut bir hastalığa neden olabilir. Hidrokarbon bileşiklerinin özellikle ev içinde su, meyve suyu veya gazlı içecek şişesi gibi farklı ambalailarda saklanması çocukların bu maddeyi yanlışlıkla içmesini kolaylaştıran faktörlerdir. Spesifik klinik ve radyolojik bulgularının olmaması nedeniyle güçlü şüphe yoksa ve anamnezde bilgi elde edilememişse tanıda zorluklara yol açabilir. Daha çok çocukluk çağının ciddi zehirlenmeleri arasında olmasına rağmen burada erişkin yaşta tanı koyduğumuz iki lipoid pnömoni olgusunu sunuyoruz.

Anahtar Sözcükler: Lipoid pnömoni, hidrokarbon, aspirasyon.

\footnotetext{
'Department of Chest Diseases, Recep Tayyip Erdoğan University Faculty of Medicine, Rize, Turkey

${ }^{2}$ Department of Infectious Diseases, Recep Tayyip Erdoğan University Faculty of Medicine, Rize, Turkey

\author{
'Recep Tayyip Erdoğan Üniversitesi Tıp Fakültesi, Göğüs \\ Hastalıkları Anabilim Dalı, Rize
}

${ }^{2}$ Recep Tayyip Erdoğan Üniversitesi Tıp Fakültesi, Enfeksiyon Hastalıkları Anabilim Dalı, Rize
}

Submitted (Başvuru tarihi): 10.12.2014 Accepted (Kabul tarihi): 09.01.2015

Correspondence (iletişim): Songül Özyurt, Department of Chest Diseases, Recep Tayyip Erdoğan University Faculty of Medicine, Rize, Turkey

e-mail: drsongul@gmail.com 
Exogenous lipoid pneumonia, as a result of the aspiration and inhalation of fat or hydrocarbon products, are rare clinical cases, first reported by Laughlen in 1925 (1). It may cause a wide spectrum of symptoms, ranging from mild clinical symptoms, to serious respiratory failure. Acute cases are typically the results of the substantial aspiration of oil-based products (gas oil, diesel fuel, petrol, turpentine oil, etc.) $(1,2)$. Chronic cases are generally observed in older patients and it is generally the result of the repeated aspiration or inhalation of animal, vegetable or mineral fats (1). Since its clinical and radiological characteristics are similar to those of bacterial pneumonia, anamnesis is an important part of the diagnosis (3). Here, we present a case of a 21 -year-old tractor driver emerging as a result of diesel aspiration via absorption from the tank of his vehicle and a 44 -year-old patient with Down syndrome emerging as a result of drinking a water glass of diesel.

\section{CASE}

Case 1: A twenty one year old tractor driver aspirated diesel while siphoning it from the tank of his vehicle. The patient stated that he aspirated approximately a water glass of diesel. Following aspiration, he applied to a community clinic due to complaints such as coughing, choking, pleuritic chest pain, hemoptysis and the sense of burning in the chest. He was, directed to our emergency department. In the physical consultation with the patient, he was conscious and, cooperative; tachypnea (respiratory rate was $22 / \mathrm{min}$ ), the temparature was $38^{\circ} \mathrm{C}$, arterial tension $110 / 70 \mathrm{mmHg}$, mucosae were cyanotic and the oxygen saturation in the room air was detected as $84 \%$. In the auscultation, mild rales were heard in the right basal. In the laboratory findings, WBC $18.5 \mathrm{~K} / \mathrm{uL}$ (\%92 neutrophil), CRP: $1.66 \mathrm{mg} / \mathrm{dl}$, and sedimentation was detected as $4 \mathrm{~mm} /$ hour. Biochemical values were ordinary. He had a thorax CT in the emergency department. Pneumonic consolidation was detected in the right lung's middle lobe (Figure 1). The patient was hospitalized in the pulmonary diseases department due to diagnosis of lipoid pneumonia based on hydrocarbon aspiration. He was given empiric antibiotics (ampicillin/sulbactam 4x 1 gram intravenous), 2-3 L/min nasal oxygen, and 40 $\mathrm{mg} /$ day IV prednisolone. The patient had a bronchoscopy. Mucosal hyperemia was detected in right intermediary bronchus and middle lobe as well as the lower lobe bronchi. Bronchial lavage and a pathological examination of the bronchial mucosa biopsy reported non-specific inflammation. He was diagnosed with lipoid pneumonia, based on anamnesis, as well as clinical and radiological findings. After one-week's treatment, the patient, who did not need oxygen, was monitored in the room air. At the end of a two week-period, the patient showed radiological and clinical recovery. He was discharged from the hospital but his control examinations could not be carried out since he did not come back for his controls.

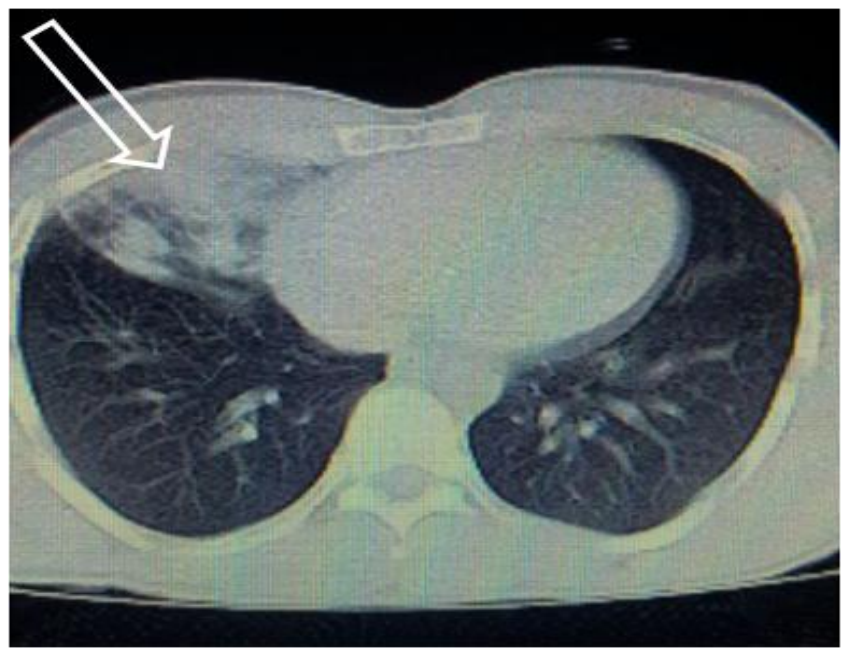

Figure 1: Consolidation on right lung middle lobe (white arrow)

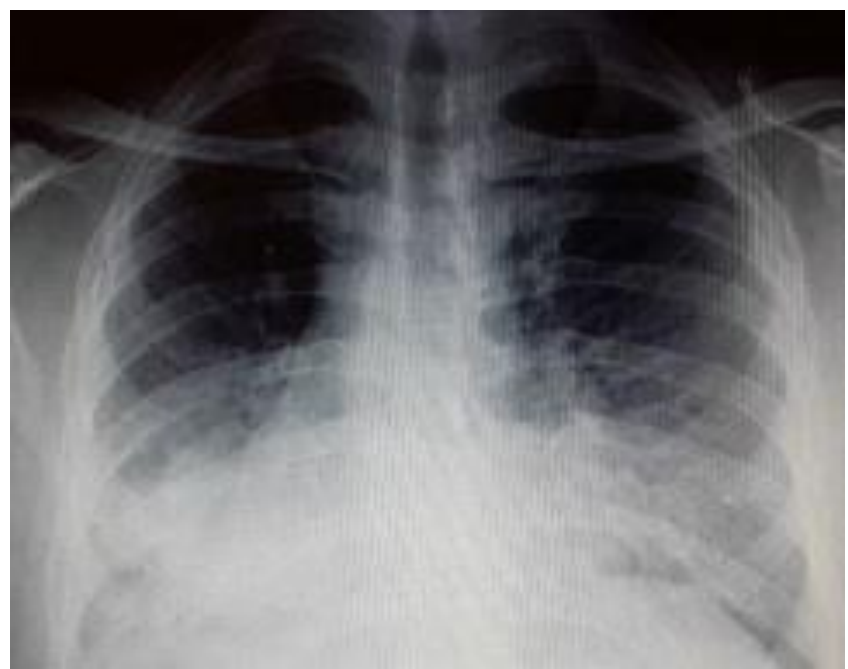

Figure 2: Heterogenic consolidation in bilateral lower zones of lung

Case 2: A 44-year-old patient with Down syndrome, on a tour, suddenly drank a water glass of liquid that was on the table. Following this, he started to vomit and had difficulty in breathing. As a result of these complaints he was brought to the emergency department. Based on the statements of the storeowner it became clear that the liquid was petrol based. Tachypnea (the respiratory rate $32 / \mathrm{min}$ ) was measured. Stertorous respiration and cyanosed tachycardia (pulse 134/min) were detected. Oxygen saturation of the fingertip in the room air was $86 \%$, the temperature was $37^{\circ} \mathrm{C}$, and arterial tension was 
measured as $100 / 60 \mathrm{mmHg}$. In the auscultation, bilateral mild rales were heard. In the chest $\mathrm{x}$-ray, heterogeneous infiltration, more obvious in bilateral lower zones' paracardiac areas, was detected (Figure 2). In the thorax $\mathrm{CT}$, there was infiltration in the bilateral upper lobes (Figure 3). Laboratory findings were as follows: WBC: 12 $\mathrm{K} / \mathrm{uL}, \mathrm{CRP}: 14 \mathrm{mg} / \mathrm{dl}$, sedimentation $17 \mathrm{~mm} /$ hour. There were no pathological findings in the blood biochemistry. Arterial blood gas values during the implementation of nasal oxygen for $4 \mathrm{~L} / \mathrm{min}$ in the emergency were as follows: $\mathrm{pH}:$ 7.40, $\mathrm{PCO}_{2}:$ 33.9, $\mathrm{PO}_{2}:$ 56.4, oxygen saturation $90 \%$. The patient was hospitalized in the pulmonary diseases department. Treatment consisting of empiric antibiotic (ampicillin/sulbactam 4x1 gram intravenous and levofloxacin $400 \mathrm{mg}$ intravenous), $2 \mathrm{~L} / \mathrm{min}$ nasal oxygen, $60 \mathrm{mg} /$ day IV prednisolone, was initiated. Due to the patient having Down syndrome there was difficulty in cooperation and as a result the bronchoscopy could not be carried out. This case was also diagnosed as lipoid pneumonia, based on anamnesis, as well as clinical and radiological findings. After three-week's treatment in our clinic, in addition to his laboratory findings, which were ordinary, the overall situation of the patient indicated recovery. For over a month the patient applied to the hospital due to an intermittent cough. A thorax CT was carried out, which indicated cavitation with proper contour in the left lower lobe posterior (Figure 4). The values were CRP: 7, sedimentation $55 \mathrm{~mm} / \mathrm{h}, \mathrm{WBC}: 13 \mathrm{~K} / \mathrm{uL}$. Moxifloxacin $400 \mathrm{mg}$ p.o. was implemented for 14 days. A thorax CT was carried out once again after a month (Figure 5) and the laboratory findings were normal.

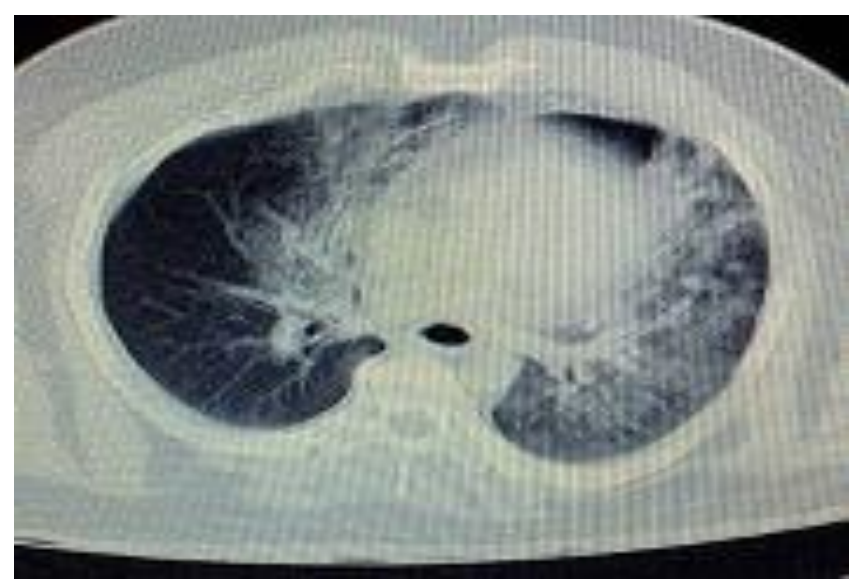

Figure 3: Consolidation and ground glass opacities in right lung middle lobe, left lung lingular segment and left lung lower lobe

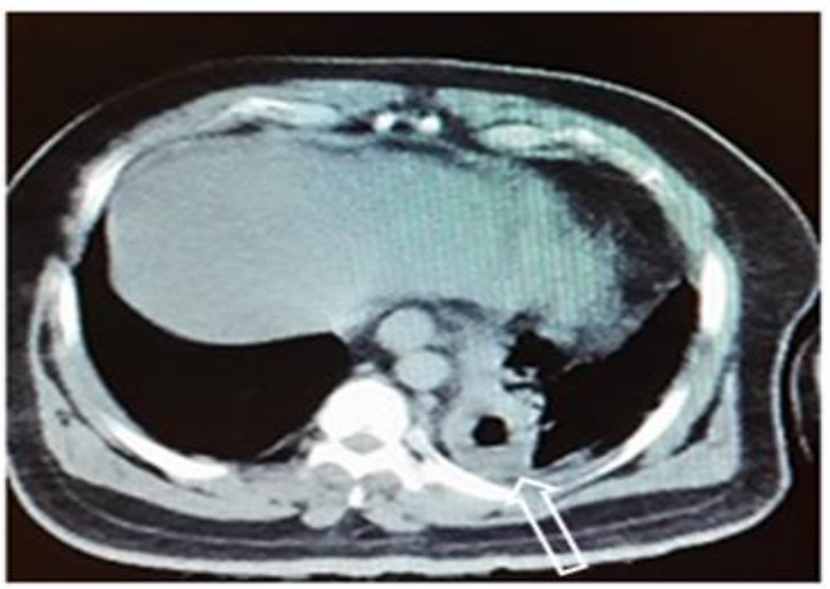

Figure 4: A thick-walled cavitary lesion with $4 \mathrm{~cm}$ diameter in left lung lower lobe medio-basal segment (white arrow)

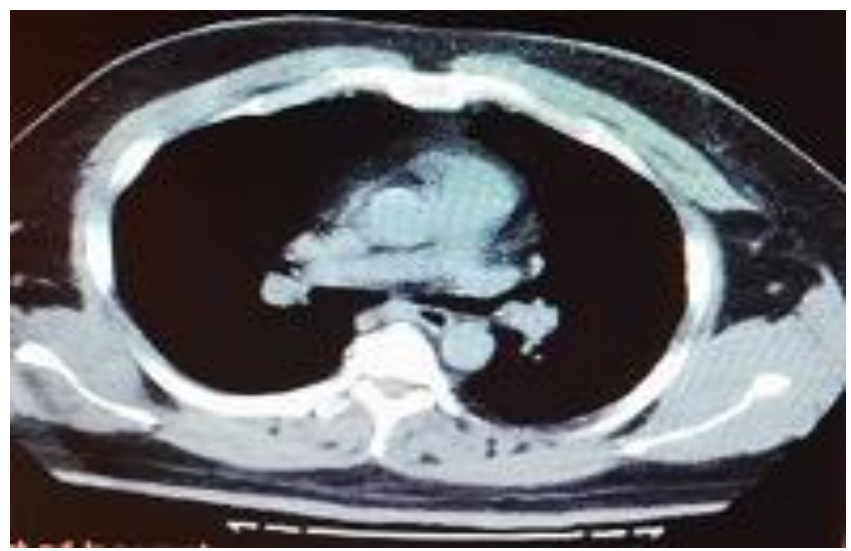

Figure 5: Normal lung CT image (after treatment of pneumonia)

\section{DISCUSSION}

Hydrocarbons are chemical substances that can be found in many everyday products. Hydrocarbon poisoning is more common in children and people with mental health problems $(1,2)$. Accidents may occur when these chemicals are stored in inappropriate and unlabeled containers in accessible places. The most important toxic effect is aspiration pneumonia following oral ingestion $(2,3)$. This is because these substances have low viscosity that makes it easier to transit from the hypopharynx to the larynx. In adults, it can occur when there is aspiration while orally syphoning diesel or petrol based products from a vehicle, as first of our cases. Furthermore, cases have been reported as developing in performers who eat or swallow fire, due to the aspiration of liquid hydrocarbons mixtures (4). These kinds of lipoid pneumonias are classified as exogenous lipoid pneumonia $(1,3)$. Endogenous lipoid pneumonias are rare and are also known as cholesterol pneumonia. They appear in bronchial obstruction distal or from the walls of destroyed alveoli, in areas of chronic 
suppuration, or due to other kinds of diseases such as lipid storage disorder $(1,5,6)$. Other reasons that facilitate exogenous lipoid pneumonia are: advanced age, mental health disorders, aphagia, anatomical and structural abnormalities of pharynx and larynx, gastroesophageal reflux, hiatal hernia, Zenker's diverticulum, achalasia and etc., as well as psychogenic disorders and neuromuscular diseases (5).

Clinical lipoid pneumonia depends on the amount of aspirated substance, as well as the aspiration period. It may have sudden onset, due to an enormous amount of substance being aspirated or slow onset, due to the chronic aspiration of a substance in small quantities $(1,5)$. Symptoms may appear instantly or hours after the aspiration. Symptoms may be mild but it is also possible to have substantial respiratory insufficiency that requires mechanic ventilation, consisting of symptoms like cough, dyspnea, chest pain, hemoptysis and fever $(1,5,7,8)$. Both cases applied to emergency due to cough, difficulty in breathing, chest pain and fever. The first case also had hemoptysis. Findings in the physical consultation may be ordinary, while rales and rhonchi are also possible (5). Laboratory, physical and radiological findings are not specific to the disease. It may be difficult to distinguish the disease from bacterial pneumonia, tuberculosis, and cystic fibrosis. Therefore, anamnesis is an important part of the diagnosis $(1,5,8)$.

Radiological findings may appear within 30 minutes of the aspiration or in the subsequent 24 hours $(1,5)$. A chest $\mathrm{x}$-ray may indicate diffusive or integrative consolidations, opacities with improper bilateral borders, lesions similar to irregular bulks, bilateral-symmetrical reticuloendothelial infiltration, alveolar-intersystol patterns, and unilateral or bilateral nodular lesions $(1,3,5)$. Highresolution $\mathrm{CT}$ is more helpful in diagnosis that aids the detection of a ground-glass appearance, crazy paving, consolidations consist of air bronchograms, lesions similar to bulky and interlobular thickenings (5). On rare occasion, it is possible to observe pneumatocele, pneumothorax and pleural effusion $(1,5)$. Though there are no radiological findings specific to lipoid pneumonia, lowdensity consolidations in the thorax CT (between -30 to $150 \mathrm{HU}$ ) support lipoid pneumonia when evaluated with anamnesis $(1,2,5)$. Aspiration is generally observed in the middle and lower lobes. While in the first case the aspiration was in right middle lobe, in the second case infiltration was detected in both upper lobes. It was reported that the resolution of radiological opacities are between two weeks and eight months (1).
Inflammatory findings and edema may be observed in the bronchoscopic examination $(1,8)$. In the first case, mucosal hyperemia and edema were detected in right intermediary bronchi, middle lobe and basal segments via bronchoscopy. Bronchoalveolar lavage liquid and lipid-laden macrophages in needle biopsy samples support the diagnosis $(1,3,5)$. In our cases, biopsy and lavage were reported as non-specific inflammatory reaction. In the second case, a bronchoscopy could not be made since the patient was non-cooperative.

The role of antibiotics in the treatment of lipoid pneumonia is disputable; however, antibiotics are used in most cases to avoid superinfection $(2,3,5,8)$. Again, though their role in treatment is debatable, corticosteroids are used, due to their effects in preventing anti-inflammatory and fibrosis developments $(2,5,7)$. In both cases, we implemented corticosteroid and empiric antibiotic treatment. Also, it was reported that repeated lung lavage is also beneficial in the treatment $(2,5)$. Additionally, oxygen support, as well as other support treatments, can be employed for respiratory insufficiency (5). With approximately $2 \mathrm{~L} / \mathrm{min}$ nasal oxygen support for one week in both our cases, their saturation in room air was unremarkable. The cases, which indicated both clinical and radiological recovery, were discharged from the hospital.

In conclusion, exogenous lipoid pneumonia based on hydrocarbon aspiration may lead to various clinical findings, ranging from mild clinical to life threatening, such as respiratory insufficiency. It is difficult to distinguish from bacterial pneumonia unless anamnesis is taken. It may lead to complications such as abscesses, fistula, pleural effusion, etc. It must be kept in mind that the use of antibiotics and steroids is disputable.

\section{CONFLICTS OF INTEREST}

None declared.

\section{AUTHOR CONTRIBUTIONS}

Concept - S.Ö., M.K., A.G., H.Ç., A.E., S.K., Ü.Ş.; Planning and Design - S.Ö., M.K., A.G., H.Ç., A.E., S.K., Ü.S.; Supervision - S.Ö., M.K., A.G., H.Ç., A.E., S.K., Ü.Ş.; Funding - S.Ö.; Materials - S.Ö.; Data Collection and/or Processing - S.Ö.; Analysis and/or Interpretation S.Ö.; Literature Review - S.Ö.; Writing - S.Ö.; Critical Review - S.Ö.

\section{YAZAR KATKILARI}

Fikir - S.Ö., M.K., A.G., H.Ç., A.E., S.K., Ü.Ş.; Tasarım ve Dizayn - S.Ö., M.K., A.G., H.Ç., A.E., S.K., Ü.Ş.; 
Denetleme - S.Ö., M.K., A.G., H.Ç., A.E., S.K., Ü.Ş.; Kaynaklar - S.Ö.; Malzemeler - S.Ö.; Veri Toplama ve/veya İşleme - S.Ö.; Analiz ve/veya Yorum - S.Ö.; Literatür Taraması - S.Ö.; Yazıyı Yazan - S.Ö.; Eleştirel Inceleme - S.Ö.

\section{REFERENCES}

1. Betancourt SL, Martinez-Jimenez S, Rossi SE, Truong MT, Carrillo J, Erasmus JJ. Lipoid pneumonia: spectrum of clinical and radiologic manifestations. AJR Am J Roentgenol 2010; 194:103-9. [CrossRef]

2. Venkatnarayan K, Madan K, Walia R, Kumar J, Jain D, Guleria R. "Diesel siphoner's lung": Exogenous lipoid pneumonia following hydrocarbon aspiration. Lung India 2014; $31: 63-6$. [CrossRef]

3. Sias SM, Ferreira AS, Daltro PA, Caetano RL, Moreira Jda S, Quirico-Santos T. Evolution of exogenous lipoid pneumonia in children: clinical aspects, radiological aspects and the role of bronchoalveolar lavage. J Bras Pneumol 2009; 35:839-45.
4. Torun E, Çağlayan B, Durmuş N, Eren A, Erdem I, Aktürk ÜA ve ark. Ateş yiyenlerin pnömonisi. J Kartal TR 2004; 15:105-7.

5. Marchiori E, Zanetti G, Mano CM, Hochhegger B. Exogenous lipoid pneumonia. Clinical and radiological manifestations. Respir Med 2011; 105:659-66. [CrossRef]

6. Lococo F, Cesario A, Porziella V, Mulè A, Petrone G, Margaritora $S$, et al. Idiopathic lipoid pneumonia successfully treated with prednisolone. Heart Lung 2012; 41:184-7. [CrossRef]

7. Karakoç T, Ekici A, Ekici MS, Bulcun E, Alıınkaya V, Şentürk E ve ark. Hidrokarbon aspirasyonuna bağlı lipoid pnömoni olgusu. Solunum Hastalıkları 2008; 19:37-40.

8. Taş D, Demirer E, Çiftçi F, Okutan O, Kartaloğlu Z. Lipoid pneumonia caused by diesel fuel aspiration: a case report. Respir Case Rep 2012; 1:8-11. [CrossRef] 